\title{
DEKONSTRUKSI KEMANUSIAAN MASYARAKAT CEMPAKA DALAM NOVEL GALUH HATI KARYA RANDU ALAMSYAH
}

\author{
Endang Sulistyowati ${ }^{1}$ \\ 1. Pendidikan Bahasa dan Sastra Indonesia STKIP PGRI Banjarmasin \\ endangsulistyowati56@gmail.com
}

\begin{abstract}
ABSTRAK
Penelitian ini bertujuan mengungkapkan dekonstruksi kemanusiaan dalam masyarakat Cempaka dalam novel Galuh Hati karya Randu Alamsyah. Pendekatan penelitian ini menggunakan teori dekonstruksi yang berusaha membongkar dan mengungkapkan unsur kebahasaan yang berwujud teks dalam novel, sehingga menemukan realitas kemanusiaan masyarakat Cempaka yang difokuskan pada aspek kemanusiaa berwujud pemikiran, perilaku dan interaksi sosial tokoh. Jenis penelitian ini adalah deskriptif kualitatif, data penelitian berupa satuan cerita berwujud kata, frasa, kalimat dan wacana yang terdapat dalam novel Galuh Hati. Teknik analisis data dengan pembacaan setelah dilakukan pembongkaran teks secara analitis, kritis dan pemahaman secara mendalam sehingga diperoleh totalitas makna. Hasil penelitian ini mengemukakan dekosntruksi kemanusiaan dalam masyarakat Cempaka, meliputi: 1) Pandangan hidup yang meliputi pendidikan, dan kegiatan ekonomi; 2) cinta kasih sayang meliputi, kasih sayang dalam hubungan Ayah dan anak, hubungan persahabatan, serta hubungan dalam lingkup sosial masyarakat; dan 3) tanggung jawab meliputi tanggung jawab Ayah, anak, dan tanggung jawab moral masyarakat. Pembongkaran pada teks sastra yang menggunakan teori dekonstruksi mengungkapkan beberapa aspek kemanusiaan meliputi, belum tercapainya pemerataan infrastruktur bagi masyarakar desa, pendeskriminasian bagi suatu kelompok tertentu dan kebenaran yang bersifat relatif.
\end{abstract}

Kata Kunci: Dekonstruksi, Kemanusiaan, Masyarakat Cempaka, Galuh Hati

\section{PENDAHULUAN}

Manusia saat ini telah mengalami perubahan dan perkembangan yang signifikan mulai dari manusia sebagai makhluk sosial, makhluk individual, makhluk gemar seni, dsb. Melalui pandangan humanis manusia memiliki dorongan dalam diri untuk mencapai tujuan positif sehingga menuntut mereka untuk bertindak rasional. Kemanusiaan merupakan suatu istilah yang digunakan yang berkaitan dengan kehidupan, permasalahan, perkembangan dan dimanika kehidupan manusia. Pengungkapan mengenai definisi manusia tersebut akan muncul melalui berbagai penelitian yang kemudian diabadikan melalui tulisan atau dipatenkan menjadi sebuah pengetahuan. Saat ini masalah kemanusiaan juga sering diungkapkan dalam karya sastra sebagai wujud pencerminan realitas kehidupan manusia. 
Berbagai ahli filsafat humaniora merumuskan beberapa definisi manusia yaitu sebagai makhluk yang berbudi, makhluk yang pandai membuat peralatan dari bahan alam untuk kebutuhan hidupnya, makhluk ekonomi, makhluk beragama dan makhluk yang pandang menciptakan bahasa (dalam Drijarkara, 1987: 138). Keberadaan manusia di muka bumi memberikan pergolakan dan kehidupan yang kompleks bagi semua makhluk. Kecerdasan pikiran dan emosional yang dimiliki manusia selalu menjadi daya tarik yang menarik untuk dijadikan objek penelitian, sebab hasilnya akan mengungkapkan bagaiman perkembangan pola pikir, gaya hidup, dan kebiasaan manusia dari waktu ke waktu. Daulay (2009: 11), mengungkapkan bahwa melalui sisi yang berbeda perkembangan dan kemajuan tekonologi secara bersamaan telah membelenggu manusia dalam hasil-hasil ciptaan tersebut yang mengkontruksi sifat kebenaran yang 'baru'.

Sisi kemanusiaan menjadi pembahasan yang selalu menarik karena akan mengungkapkan ciri khas dari manusia dan kehidupan. Pengungkapan aspek kemanusiaan ini dapat menjadi ilmu pengetahuan bagi manusia yang bertumpu pada kebenaran dan fakta yang ada. Akan tetapi, Derrida melalui teori dekonstruksi membantah bahwa realitas menjadi bukti kebenaran yang harus diterima oleh masyarakat. Al-Fayyadl (2011: 82), mengungkapkan bahwa dengan suatu pembacaan yang dominan melalui dekonstruksi membuat pemaknaan menjadi bersifat majemuk dan melebar kea rah lain yang hasilnya tidak dapat dikendalikan. Konsep dekonstruksi mengungkapkan bahwa realitas tidak dapat selalu merepresentasikan kebenaran yang ada, khususnya dalam aspek kemanusiaan. Turiman (2015: 310), menyatakan bahwa dekonstruksi menyangkal dominasi totalitas yang menyatakan realitas adalah satu serta menuntun manusia ke dalam sistem dan menentang konsep esensi mengenai konsep pengetahuan mendasari sesuatu.

Dekonstruksi memandang teks dalam bahasa karya sastra merupakan hal yang kompleks artinya, dapat menimbulkan berbagai penafsiran makna. Derrida (1976: 158-159), sebagai pakar dekonstruksi mengemukakan bahwa sebuah struktur dalam studi sosial, sastra atau sains perlu dilakukan perombakan dengan cara rekonstruksi pemikiran untuk membebaskan pemikiran pembaca. Di sisi lain Endraswara (2013: 170), menyatakan bahwa makna dalam teks juga bisa rumit yang memungkinkan pembaca berspekulasi makna. Makna tidak tunggal, melaikan bersifat plural, makna bukan mati (tetap) melaikankan hidup dan berkembang. Karenanya, dekonstruksi membiarkan teks itu ambigu dan menantang segala kemungkinan. Struktur yang menyusun makna sebenarnya merupakan awal pencarian makna, untuk menemukan makna yang lebih kuat dan meyakinkan. Caranya dengan menggunakan dekonstruksi yang membongkar, membedah teks agar terlepas dari dari struktur yang ada. Oktaviantina (2014: 67), menambahkan bahwa dekonstruksi tidak mengabaikan kontruksi, namun membongkar makna melalui struktur seperti tokoh, karena memiliki peran penting dalam pembongkaran makna.

Strukturalis tradisional mengaggap bahwa sesuatu yang diungkapkan dalam teks merupakan suatu kenyataan sehingga dapat membangun realitas dan keyakinan masyarakat. Hal tersebut dibangun didasarkan adanya penegasan dari struktur, data dan fenomena serta menjadi suatu pengetahuan akan dunia mereka. Guney and Guney (2008: 221), menyatakan bahwa teori Derida hadir untuk dengan menawarkan post-strukturalis yang memberikan cara berpikir baru melalui sudut pandang berbeda 
dengan menyatakan bahwa suatu kebenaran itu tidak dapat diketahui secara pasti, karena semua hanya dibangun melalui kata-kata dan keyakinan yang pasif. Sebagai contoh penerapan teori Derrida, seorang perempuan dinilai kecantikannya hanya melalui warna kulit, rambut, bentuk tubuh dan ciri fisik lainnya. Dalam Penerapan teori Derrida masih terdapat kemungkinan-kemungkinan mengenai perempuan cantik yang tidak hanya didasarkan pada aspek tersebut seperti berlesung pipi, mata bulat, cara bersikap, dll. Berdasarkan penjelasan tersebut teori Derrida berupaya mengemukakan irisan-irisan suatu fakta yang mungkin tidak disadari oleh masyarakat.

Beberapa teks sastra ada yang memuat kode-kode lain diluar teks, karena itu kita perlu memahami kode tersebut dengan memperbolehkan pembaca berimajinasi untuk menciptakan kembali dunia rekaan berdasarkan teks sastra tersebut. Sejalan dengan hal tersebut Yegen (2014: 57), menyatakan bahwa teks konvensional memiliki distorsi makna, dengan kata lain bahwa dalam makna teks tersebut masih memiliki kemungkinan mengarah pada makna dan presepsi yang lain. Hal ini dianggap dapat memudahkan sastra untuk dipahami dan diterima maknanya. Pemikiran tersebut memang agak menyimpang dan aneh, tapi lewat cara itu dekonstruksi dapat memandang perbedaan-perbedaan sastra tidak hanya melihat persamaan-persamaan saja.

Catatan penting dari penelitian dekonstruksi adalah makna teks sastra sebenarnya bisa berubah-ubah. Makna sebuah teks bisa bermacam-macam dan tidak memusat. Teks sastra yang bersifat polisemi dan lebih penting, pemaknaan dekonstruktif boleh ke arah gerakan futuristik (Endaswara, 2013; 176). Pendekatan ini ingin berusaha melengkapi atau melawan model penelitian lama yang dianggap gagal memahami teks sastra yang sekarang ini semakin berkembang. Sastra sekarang ini lebih kompleks, berbetuk spektakuler, bebas berimajinasi yang bahkan keluar dari struktur.

Desa Cempaka merupakan salah satu wilayah yang berada di kota Banjarbaru, yang merupakan kawasan penambang intan dan emas tradisional yang menjadi salah satu ciri khas daerah sekaligus mata pencaharian utama masyarakat Cempaka. Hasil intan dan emas dari Desa Cempaka merupakan salah satu yang terbaik di Dunia, sehingga banyak banyak turis lokal maupun internasional yang datang berkunjung. Kekayaan sumber daya alam tidak memberikan keuntungan besar bagi masyarakat Cempaka, mereka seakan hanya menjadi korban dari gemerlapnya Intan yang berprestise dan mahal. Pendulang intan di Masyarakat Cempaka mengalami kondisi kehidupan yang meprihatinkan baik dalam aspek ekonomi, pendidikan, kesehatan bahkan infrastruktur.

Galuh Hati salah satu novel bercorak kearifan lokal mengungkapkan dinamika kehidupan kemanusiaan masyarakat Banjar. Masyarakat Cempaka yang diungkapkan dalam novel Galuh Hati menjalani kehidupan dengan penuh konflik dan permasalahan namun tetap berusaha memegang teguh prinsip mereka sebagai manusia yang berbudaya. Perkembangan teknologi yang memberikan kemudahan dalam aspek kehidupan tidak berpengaruh signifikan bagi masyarakat Cempaka, yang mereka tau hanyalah bagaimana menjalani kehidupan yang terimpit dengan keterbatasan. Berdasarkan hal tersebut, novel Galuh Hati menarik untuk diteliti 
karena hasilnya akan membongkar bagaimana dinamika perkembangan teknologi dan perubahan sosial tidak mempengaruhi aspek kemanusiaan masyarakat Cempaka.

Teori dekonstruksi memiliki keterkaitan erat dengan sastra, karena karya sastra merupakan cerminan dari realitas kehidupan. Pengungkapan realitas kehidupan dalam karya sastra paling dominan berhubungan dengan kemanusiaan, karena manusia selalu adaptif dan dinamis sebagai makhluk dengan otoritas akan kehidupannya sendiri. Zulfikar, dkk. (2017: 147), menyatakan bahwa manusia sebagai makhluk sadar, mandiri, aktif serta bertanggung jawab dalam segala aktivitas yang dilakukannya. Lebih lanjut, Daulay (2002: 12), menyatakan bahwa manusia memiliki kedudukan yang sama, saling bersaudara dan menciptakan rasa cinta kasih sayang. Berdasarkan dua definisi tersebut, maka dapat dikatakan bahwa manusia adalah makluk yang setara antara satu dengan yang lainnya walaupun dengan dinamika perubahan yang terjadi namun tetap memiliki otoritas penuh atas segala hal dalam hidupnya. Berdasarkan hal tersebut, maka penelitian ini secara mendalam akan mengaplikasikan teori dekonstruksi terkait masalah kemanusiaan yang berwujud pandangan hidup, cinta kasih sayang, dan tanggung jawab yang termuat dalam novel Galuh Hati.

\section{METODE PENELITIAN}

Pendekatan yang digunakan penelitian adalah pendekatan dekonstruksi. Pendekatan dekontruksi dilipih karena karya sastra tidak terpaku pada suatu makna yang sebenarnya secara struktur akan tetapi masih diperlukan pembongkaran secara cermat untuk mengungkapkan makna atau pesan tersembunyi dari penulis. Penelitian difokuskan pada aspek kemanusiaan yang berwujud pemikiran, perilaku dan interaksi sosial tokoh. Sejalan dengan hal tersebut, Hakim (2013: 4), mengungkapkan bahwa dekonstruksi menghidupkan kekuatan-kekuatan tersembunyi yang turut membangun teks dan kebudayaan sebagai suatu tatanan makna yang utuh. Metode penelitian yaitu semiotik struktural dengan cara mengeksplorasi simbol atau tanda bahasa dalam novel dengan cara pembongkaran makna secara cermat dan mendalam. Data penelitian berupa satuan cerita berwujud kata, frasa, kalimat dan wacana yang terdapat dalam novel Galuh Hati. Pengumpulan data melalui studi kepustakaan terhadap novel sebagai sumber utama serta penelusuran sumber pustaka kemanusiaan dan dekonstruksi sastra. Analisis penelitian dilakukan dengan pembacaan setelah dilakukan pembongkaran teks secara analitis, kritis dan pemahaman secara mendalam sehingga diperoleh totalitas makna.

\section{HASIL DAN PEMBAHASAN}

Novel Galuh Hati karya Randu mengulas mengenai kehidupan masyarakat Desa Cempaka di Kalimantan Selatan sebagai salah satu penghasil intan terbaik di dunia. Kehidupan masyarakat masih tertinggal jauh dari peradaban dan kemajuan teknologi. Kehidupan masyarakat masih dilakukan secara tradisional, baik dari aktivitas, teknologi, mata pencaharian dan pengetahuan. Yulianto (2017: 62), dalam penelitiannya mengungkapkan bahwa Galuh Hati sarat akan warna lokal sekaligus kritik sosial mengenai kegiatan pendulangan intan yang menggambarkan poal hidup 
masyarakat Cempaka yang seakan terjebak dalam ketidakpastian dan kemiskinan. Kondisi seperti ini bukanlah kehendak masyarakat, melainkan sebuah kondisi tertentu yang memaksa mereka untuk mengalami keadaan tersebut.

\section{A. Dekonstruksi Kemanusiaan Berwujud Pandangan Hidup}

Tokoh Abul menjadi fokus dalam pendekatan dekonstruksi, karena penulis secara tidak langsung dalam alur cerita dan peristiwa menggambarkan Abul dan keluarganya berbeda dengan keluarga yang dianggap normal di Desa Cempaka. Warga yang dianggap normal di Masyarakat Cempaka adalah keluarganya menjadi pendulang intan, sementara Abul malah tetap disuruh bersekolah oleh Ayahnya saat teman seusianya telah putus sekolah karena masalah ekonomi, dan terpaksa menjadi pendulang. Hal tersebut terdapat pada kutipan berikut.

[1] "Aku tidak mendulang semenjak kecelakaan yang menimpa Ayahku. Dia melarangku pergi mendulang. Dia ingin aku melakukan untuknya apa yang selalu diimpikan sejak kecil, menjadi seseorang yang terpelajar." (Alamsyah, 2014: 129).

Apabila dilakukan analisis secara mendalam, melalui kutipan [1] menunjukkan bahwa ayah Abul merasa bersalah dengan keadaan dirinya, penyesalan yang dia dapatkan membuatnya menginginkan kehidupan yang lebih baik untuk Abul. Kehidupan yang lebih menjanjikan dan tidak memiliki resiko besar yang dialami oleh Ayahnya atau pendulang lain yang mengalami kecelakaan atau meninggal dunia di pendulangan. Bercermin dari kejadian dari Ayah Abul, dia tidak ingin anaknya mengalami kehidupan yang keras dan penuh resiko, dia memiliki pandangan hidup yang berbeda dari masyarakat Cempaka secara umum, yaitu menyekolahkan anaknya agar mendapatkan taraf hidup yang lebih baik, seperti pada kutipan berikut.

[2] Tapi, meski kecintaan Ayah pada tanah pendulangan begitu besar, dia tak pernah menyuruhku mendulang intan. Seperti seorang remaja yang tidak mau cinta pertamanya direbut, Ayah mengalihkan perhatianku ke hal-hal lain. Alih-alih menggantungkan seragamnku, Ayah menyuruhku untuk tetap melanjutkan sekolah. (Alamsyah, 2014: 9)

Kutipan [2] di atas menunjukkan bahwa Ayah Abul tidak memberikan kesempatan atau tidak memperbolehkan sama sekali Abul untuk merasakan kesengsaraan mendulang intan. Ayah Abul seperti merasa bahwa cukup dirinya saja yang merasakan kesengsaraan dan kesedihan itu, sementara anaknya harus mendapatkan kehidupan yang layak, yang tentunya akan membanggakan orang tua Abul. Abul sepertinya juga telah memiliki pandangan yang sama dengan orang tuanya, dia berusaha dengan keras untuk belajar dan melanjutkan sekolah sebagai salah satu kunci kehidupan yang lebih baik, seperti pada kutipan berikut.

[3] Saat ini yang ingin aku lakukan adalah meninggalkan kampungku dan tinggal di sebuah tempat tanpa asap mesin, terik matahari garang, dan lumpur. Nilai 
Dekonstruksi Kemanusiaan Masyarakat Cempaka dalam Novel Galuh Hati Karya Randu Alamsyah

tertinggi adalah tiket bagiku untuk keluar dari tempat ini (Alamsyah, 2014: 106107)

Abul sepertinya telah memiliki tekad yang bulat untuk menujuk kehidupan yang lebih baik, dari pada di Cempaka. Sudut pandang dan pengalaman dari masyarakat Cempaka telah merubah pandangan hidupnya. Abul begitu menginginkan untuk tidak terlibat dengan pendulangan lagi, tidak ingin masa lalu kepedihan ayahnya dan tidak ingin selalu dianggap sebagai keluarga pecundang akibat pilihan hidup keluarga mereka. Abul begitu rajin dan tekun dalam belajar untuk meraih nilai tertinggi untuk dapat melanjutkan sekolah pada jenjang yang lebih tinggi.

[4] "Aku sudah menduga bahwa aku akan merasa bosan berada di pendulangan. Namun, aku tak menyangka rasa bosan ini muncul di hari pertamaku bekerja. Lubang-lubang besar dan kecil, tiang-tiang bambu bersilang-silang yang diikat dengan sabut, dan mesin genset penyedot air yang menyemburkan gumpalan asap hitam membuatku muak berada di lingkungan ini." (Alamsyah, 2014: 11)

Melalui kutipan [4] di ata terdapat amarah dalam hati Abul dengan situalis lingkungan di pendulangan, karena telah membuat sistem mata pencarian yang hanya berpatokan pada pendulangan intan. Abul telah memiliki pandangan yang berbeda mengenai pendulangan Intan tempat kebanggan masyarakat Cempaka sekaligus sumber utama mata pencaharian. Bagi Abul, pendulangan intan ini hanya memberikan kesengsaraan bagi masyarakat Cempaka yang harus rela bekerja dengan resiko mempertaruhkan kehidupan mereka.

[5] .... namun, kenyataanya itu menjadi omong kosong saat aku menyadari bahwa tidak ada perut seorang pendulang pun yang bisa kenyang selama tujuh hari berturut-turut karena intan yang ia temukan (Alamsyah, 2014: 22).

Pengarang berusaha mengungkapkan mengenai realitas kehidupan perekonomian masyarakat Cempaka sebagai pendulang Intan. Gemerlapnya intan dan permata tidak memberikan keuntungan yang besar bagi para pendulang, malah sebaliknya mereka harus bersusah payah bekerja hanya untuk memberikan kesenangan dan kemewahan bagi orang lain. Taraf hidup mereka tidak meningkat hanya dengan mendulang intan karena terdapat banyak pihak yang mengambil keuntungan besar dari jerih payah mereka. Realitas kemanusiaan inilah yang berusaha diungkapkan pengarang mengenai kenyataan keadaan kehidupan masyarakat Cempaka sebenarnya. Akan tetapi, pandangan hidup masyarakat cempaka sepertinya akan selalu menganggap bahwa mendulang intan adalah pekerjaan yang paling baik dan memiliki keistimewaan tersendiri, sehingga mereka mengabaikan masalah pendidikan dan kesejahteraan anak-anak dan keluarga dengan mengesampingkan sekolah.

[6] "Tidak bisa, Nak."

Dia melihatku dan tampak terluka. Sesuatu di wajahnya menusukku dan sesaat aku turut merasakan aib menjadi sebuah keluarga yang miskin. 
"Tentu saja jika Ayah mau, Ayah akan menyekolahkan semua anak di sini bukan hanya semata Anang. Kau tahu tentang keluarga kita. Ini tentang ibumu." (Alamsyah, 2014: 268)

Pada data [6] pandangan hidup Abul dan Ayahnya tampaknya memiliki perbedaan tersendiri, mereka menginginkan kehidupan yang lebih baik di masyarakat Cempaka. Mereka menginginkan masyarakat Cempaka sebagai pendulang intan yang juga mengenyam pendidikan dan memiliki pengetahuan dan wawasan yang luas. Keterbasan ekonomi yang menghalangi keinginan Abul dan seluruh masyarakat Cempaka untuk memberikan fasilitas pendidikan kepada anak-anak mereka. Keterdesakan ekonomi yang harus memaksa anak-anak di Cempaka putus sekolah dan ikut membantu mendulang untuk meringankan beban ekonomi keluarga.

Berdasarkan hasil penelitian dan pembahasan dapat diungkapkan bahwa secara dekonstruksi kemanusiaan yang berwujud pandangan hidup meliputi pendidikan dan pekerjaan yang memadai untuk kesejahteraan kehidupan. Aspek pandangan hidup ini muncul dari pemikiran pengarang yang memandang bahwa masyarakat cempaka mengesampingkan pendidikan dan mengambil resiko yang sulit dalam memilih pekerjaan.

\section{B. Dekonstruksi Kemanusiaan Berwujud Cinta Kasih}

Manusia secara kodrati memiliki kesetaraan hidup, terlepas dari jabatan dan status sosial yang dimiliki, oleh karena itu sudah sewajarnya jika sesama manusia memiliki rasa cinta kasih sayang. Wujud cinta kasih sayang juga ditemukan dalam novel Galuh Hati sebagai bagian dari aspek kemanusiaan. Wujud cinta kasih sayang ditunjukkan oleh Ayah Abul kepada Abul dalam hal mengenyam pendidikan, seperti pada kutipan berikut ini.

[7]...alih-alih menggantungkan seragamku, Ayah justru menyuruhku tetap melanjutkan sekolah. Dari semua atribut yang menjadikan Ayah sebagai orang Cempaka, hanya hal ini yang membuatnya berbeda. Hampir semua orang di Desaku menarik anaknya dari sekolah begitu mereka menginjak usia belasan tahun. Mereka akan dijadikan koloni yang saling menguatkan di pendulangan (Alamsyah, 2014: 9)

Data [7] tersebut apabila dilakukan analisis secara dekonstruksi maka akan mengungkapkan bahwa keinginan dan permintaan Ayah Abul agar Abul terus melanjutkan sekolah merupakan wujud dari cinta kasih sayang seorang Ayah kepada anaknya. Ayah Abul menyayangi anaknya dengan cara yang berbeda, yaitu dengan mendukung pendidikannya agar menjadi seseorang yang terpelajar, agar kelak tidak akan menjadi masyarakat cempaka yang tidak berpendidikan, agar tidak harus merasakan kesengsaraan mendulang intan atau jika tidak beruntung akan mengalami hal sama seperti ayahnya.

Wujud cinta kasih sayang dalam novel Galuh Hati juga terdapat dalam hubungan persahabatan. Gil yang sebagai peraih nilai tertinggi berhasil memperoleh 
beasiswa untuk melanjutkan sekolah di jenjang pendidikan yang lebih tinggi. Namun, karena memiliki rasa cinta kasih sayang terhadap sesama manusia yaitu pada sahabatnya, dia rela memberikan beasiswa itu, karena dia meyakinin bahwa Abul lebih membutuhkan dari pada dirinya, seperti pada kutipan berikut ini.

[8] "Karena itu, saya merasa tidak pantas mendapatkan penghargaan ini. Karena di luar sana, ada anak yang berusaha lebih keras dari saya membangun impian dari keterbatasan hidupnya. Dengan bangga saya memberikan beasiswa ini kepada teman saya Abul...." (Alamsyah, 2014: 278-279)

Kutipan teks pada data [8] menunjukkan rasa cinta kasih sayang dalam wujud persahabatan. Cinta kasih sayang Gil diwujudkan dengan berbesar hati dan ikhlas berbagai hal kepada seseorang yang dianggap lebih berhak mendapatkannya, walaupun dirinya juga menginginkannya. Gil digambarkan sebagai anak remaja dengan syndorm, secara dekonstruksi penulis berusaha membongkar realitas negatif terhadap keberadaan mereka. Pengarang berusaha menggambarkan bahwa kekurangan yang dimiliki secara fisik tidak mampu menjadi tolak ukur keterbatasan seseorang. Gil dengan keterbatasannya digambarkan berlawanan dengan realitas, yaitu sosok remaja cerdas, baik hati, berempati, berhati besar, dan rendah hati seperti pada kutipan berikut ini.

[9] “... saya memperoleh banyak buku dari Ayah saya dan saya bisa mempelajari semua soal dari bantuan internet. Berbeda dengan itu, saya tahu teman-teman saya belajar di tengah kepulan jelaga, meniti setiap tulisan tangannya sendiri di bawah lampu, dan menghitung penjumlahan dengan jari.” (Alamsyah, 2014: 278).

Selain mengenai dekonstruksi kemanusiaan berwujud cinta kasih sayang, terdapat kritik sosial yang diungkapkan oleh pengarang. Dalam kutipan [9], dapat diungkapkan hal menarik melalui dekonstruksi, bahwa desa Cempaka yang memiliki sumber daya alam yang berharga, ternyata tidak memperoleh hak pembangunan infrastrukur layaknya masyarakat di daerah lain. Padahal, Desa Cempaka hanya berjarak kurang lebih tujuh kilo meter dari kota. Berdasarkan hasil penelitian dan pembahasan, dekonstruksi kemanusiaan berwujud cinta kasih sayang meliputi dua aspek yaitu dalam hubungan ayah dan anak, hubungan persahabatan dan hubungan sosial dalam masyarakat.

\section{Dekonstruksi Kemanusiaan Berwujud Tanggung Jawab}

Tanggung jawab merupakan wujud dari kewajiban yang harus dilakukan manusia untuk memenuhi beberapa hak dalam kehidupan yang berkaitan dengan dirinya atau orang lain. dalam novel Galuh Hati beberapa bentuk tanggung jawab dapat ditemui seperti tanggung jawab seorang Ayah, seorang Anak, seorang sahabat, dan kelompok masyarakat. Namun dalam novel ini hanya akan mengungkapkan bagaimana wujud tanggung jawab seorang anak dan seorang ayah. 
[10] Aku melakukan apa yang diinginkan Ayah. Aku belajar hingga mataku berkunang-kunang. Sebagian karena memang aku ingin bisa lulus, sebagian lagi karena aku tiba-tiba mengetahui bagaimana menjadi anak yang tak pernah diberi kesempatan untuk bersekolah. (Alamsyah, 2014: 106-107)

Pada kutipan data [10] menunjukkan bahwa perjuangan dan kerja keras Abul adalah demi menuruti keinginan Ayahnya, agar mendapatkan pendidikan yang lebih baik dan akhirnya mengantarkan Abul pada taraf kehidupan yang lebih baik pula. Melalui data [10] tersebut sebenarnya adalah bentuk tanggung jawab Ayah Abul kepadanya, sebagai seorang Ayah berkewajiban untuk memberikan hak-hak anaknya salah satunya dengan pendidikan. Sebaliknya hal tersebut dianggap janggal oleh masyarakat Cempaka, mereka menganggap bahwa anak-anak mereka memiliki tanggung jawab untuk membanting tulang demi membantu perekonomian keluarga. Hal tersebut dapat dilihat melalui kutipan [10], berikut ini.

[11] .... hampir semua orang di desaku menarik anaknya dari sekolah begitu mereka menginjak usia belasan tahun. Mereka akan dijadikan koloni yang saling menguatkan di pendulangan. (Alamsyah, 2014: 9)

Kutipan [11] menunjukkan bahwa hanya Ayah abul yang bertanggung jawab terhadap anaknya, dengan memberikan pendidikan yang layak. Sementara secara umum masyarakat Cempaka menganggap bahwa seorang anak jika sudah remaja memiliki andil dalam tanggung jawab keluarga dalam hal perekonomian. Keberadaan anak-anak remaja yang putus di sekolah di pendulangan dianggap dapat meningkatkan penghasilan dan meningkatkan perekonomian keluarga, namun ternyata hal tersebut tidak sesuai keinginan, karena fenomena alam menjadi salah satu kendala pendulangan intan tak dapat digarap sesuka hati. Hal tersebut tampak pada kutipan berikut ini.

[12] Musim penghujan di Cempaka adalah waktu bagi mereka untuk melakukan pekerjaan selain menambang. Berkebun, mengail, dan membuat kumpang parang adalah pekerjaan yang mereka tinggalkan sejak Belanda membuka penambangan di Cempaka”. (Alamsyah, 2014: 11).

Pengarang pada data [12] berusaha mengungkapkan bahwa pendulangan intan sebagai mata pencaharian utama masyarakat ternyata tidak mampu memenuhi kebutuhan masyarakat selama sepanjang tahun. Fenomena alam dan perubahan lingkungan telah memberikan dampak bagi lahan pendulangan, sehingga tidak dapat di dulang pada musim penghujan. Pengungkapan realitas ini membuktikan bahwa bekerja di penambangan adalah bentuk keserakahan dan ketamakan manusia akan harta, karena pada dasarnya mereka memiliki sumber daya alam lain yang didukukung dengan sumber daya manusia yang mereka miliki.

Hal lain yang dapat diungkapkan melalui data kutipan [11] yaitu adanya kesenjangan sosial antara pendulang intan dan pembeli intan. Pendulang intan harus menghadapi resiko kerja yang besar dengan upah minimal yang harus didapatkan. Sementara para pembeli atau penikmat intan adalah kelompok masyarakat yang 
hanya mengandalkan harta untuk memenuhi koleksi sebagai penunjang prestise. Dari sudut pandang lainnya, pekerjaan yang dilakukan masyarakat Cempaka adalah wujud dari tanggung jawabnya akan kelangsungan hidup keluarganya, yang dianggap mampu memperbaiki perekonomian dengan cara singkat.

Tanggung jawab lainnya yang muncul dalam novel Galuh Hati berkaitan dengan tanggung jawab moral kepada sesama manusia. Keluarga Abul yang dianggap berbeda dengan Ayahnya yang tidak menjadi pendulang, Abul yang bersekolah bahkan harus membantu ibunya berdagang harus rela mendapatkan ejekan, cacian bahkan hinaan untuknya, seperti pada kutipan berikut ini.

[12] ...Meski dengan terus bersekolah, Ayah seperti menjerumuskanku dalam pusaran kehidupan penuh ejekan dan pengasingan. Para lelaki di kampung kami menyebut Ayah sebagai seorang yang terbuang. Tak hanya tu, berkat kehadiranku di sekolah mereka mulai mengatakan bahwa pada dasarnya kami adalah keluarga pengecut. Namun, bukan pada Ayah semua hinaan itu dilontarkan, melainkan kepadaku (Alamsyah, 2014: 9)

[13] ...Aku diminta ibu berjualan di tanah pendulangan. Secara ekonomi, hal itu memang menguntungkan, tapi di sisi lain ini membuatku seperti seorang tentara yang terjun payung sendiri ke daerah musuh. Para pendulang sialan itu akan menelanku mentah-mentah. Tidak ada seorang lelaki, setidaknya di kampungku, yang menyeduh teh dan mencuci piring di warung...(Alamsyah, 2014: 10)

[14] "Orang-orang di sini, mereka semua selalu mengejek aku."

Gil menatapku dan sedikit terkisap. (Alamsyah, 2014: 129)

Kutipan [12], [13], dan [14] menunjukkan bahwa hinaan yang diterima keluarga Abul didasarkan pada stigma dan nilai yang berlaku dalam masyarakat, meskipun secara adat dan budaya keluarga Abul tidak pernah melakukan pelanggaran. Nilai yang dibuat masyarakat Cempaka berdampak pada kondisi moral Abul dan keluarganya yang merasa terasingkan merasa berbeda bahkan menimbulkan kebencian dalam dirinya pada masyarakat Cempaka. Akibatnya keluarga Abul merasa dideskriminasi oleh lingkungannya sendiri, dianggap tidak normal dan dianggap tidak baik. Dalam novel Galuh Hati terungkap fenomena sosial yang saat ini terjadi mengenai suatu kebenaran, dalam dekonstruksi suatu kebenaran tidak berdasarkan apa fakta dan yang terlihat, namun masih harus diselidiki secara mendalam. Dekonstruksi terbukti mampu menguak fenomena ini, bahwasanya kebenaran tidak selamanya bersifat mutlak, akan tetapi selalu terdapat suatu makna atau konteks tersembunyi di dalamnya. Pada kenyatannya hal ini merupakan suatu realitas, yang menggap bahwa jika orang lain berbeda adalah suatu yang salah atau menyimpang. Hal tersebut tentu saja berpengaruh pada pola perilaku seseorang yang tidak ingin dianggap salah. Kaitannya dengan hal tersebut, masyarakat berperan penting dalam pengendalian tanggung jawab moral kepada individu, atau kelompok. 


\section{SIMPULAN DAN SARAN}

Berdasarkan hasil penelitian dan pembahasan mengenai dekonstruksi kemanusiaan masyarakat Cempaka dalam novel Galuh Hati, maka diungkapkan bahwa wujud kemanusiaan dalam novel meliputi 1) Pandangan hidup yang meliputi pendidikan, dan kegiatan ekonomi, 2) cinta kasih sayang meliputi, kasih sayang dalam hubungan Ayah dan anak, hubungan persahabatan, serta hubungan dalam lingkup sosial masyarakat dan 3) tanggung jawab meliputi tanggung jawab Ayah, anak, dan tanggung jawab moral masyarakat. Pembongkaran pada teks sastra yang menggunakan teori dekonstruksi mengungkapkan beberapa aspek kemanusiaan meliputi, belum tercapainya pemerataan infrastruktur bagi masyarakar desa, pendeskriminasian bagi suatu kelompok tertentu dan kebenaran yang bersifat relatif. Perwujudan aspek kemanusiaan ini masih memungkinkan untuk ditelaah secara mendalam menggunakan pendekatan ilmu yang lain seperti ekologi, budaya, sosial bahkan psikologis, sehingga memberikan ide dan gagasan baru kepada calon peneliti untuk semakin mengunggulkan novel bergenre warna lokal Kalimantan Selatan.

\section{DAFTAR RUJUKAN}

Alamsyah, Randu. (2014). Galuh Hati. Moka Media : Jakarta.

Al-Fayyadl, Muhammad. (2011). Derrida. Yogyakarta: LKis

Daulay, Anwar Saleh. (2002). Pendidikan Humaniora untuk Mengembangkan Wawasan Kemanusiaan dan Kebangsaan. Jurnal Ilmu Pendidikan. Jilid.9, No. 1, Hal. 9-17

Derrida, J. (1976). Of Grammatology, Trans. Gayatri Chakravorty Spiak Baltimore: John Hopkins University Press.

Endaswara, Suwardi. (2013). Metodologi Penelitian Sastra (Epistimologi, Model, Teori, dan Aplikasi). Yogyakarta: CAPS

Guney, Ajda and Guney, Kaan. (2008). A Brief Description of Jacques Derrida's Deconstruction and Hermeneutics. e-Journal of New World Sciences Academy. Vol. 3, No. 2. Page. 219-225.

Hakim, Aditya Akbar. (2013). Dekonstruksi Kehidupan Beragama dalam Novel Sang Pencerah Karya Akmal Nasery Basral. BAPALA : Jurnal Ilmiah Mahasiswa Berkala Universitas Negeri Surabaya. Vol. 1, No. 1, Hal. 1-14.

Oktaviantina, Adek Dwi. (2014). Dekonstruksi Budaya dalam Cerpen Kartini Karya Putu Wijaya. Jurnal Bébasan. Vol. 1, No. 2, Hal. 66-75.

Yagen, Ceren. (2014). Derrida and Language : Deconstruction. International Journal of Linguistics. Vol. 6, No. 2. Page : 48-61, DOI: 10.5296/ijl.v6i2.5210

Yulianto, Agus. (2017). Unsur-unsur Lokalitas dalam Noel Galuh Hati Karya Randu Alamsyah. Jurnal Kandai. Vol. 13, No. 1, Hal. 61-74.

Zulfikar, dkk. (2017). Konseling Humanistik : Sebuah Tinjaun Filosofi. Jurnal Konseling GUSJIGANG. Vol. 3, No.1 Hal. 146-151. DOI : http://dx.doi.org/10.24176/jkg.v3i1.1655 